\title{
Leveraging Generational Differences to Reduce Knowledge Transfer and Retention Issues in Public Administration
}

\author{
Reuben F. Burch $\mathrm{V}^{1}$ \& Lesley Strawderman ${ }^{1}$ \\ ${ }^{1}$ Department of Industrial and Systems Engineering, Mississippi State University, Mississippi State, MS, USA \\ Correspondence: Lesley Strawderman, Department of Industrial and Systems Engineering, Mississippi State \\ University, PO Box 9542, Mississippi State, MS, USA, 39762. Tel: 1-662-325-7214. E-mail: \\ strawderman@ise.msstate.edu
}

\author{
Received: May 13, 2014 Accepted: May 27, 2014 Online Published: October 18, 2014 \\ doi:10.5539/par.v3n2p61 URL: http://dx.doi.org/10.5539/par.v3n2p61
}

\begin{abstract}
Two of the biggest issues facing large non-profits and organizations employing civil servants today are knowledge transfer from the retiring Baby Boomers to their younger replacements, the Gamers, and the retention of those younger employees. Government and non-profit organizations should consider investing time and resources into understanding the demographic shift currently in process in the global workforce. Retirees are replaced by people 35 years old or younger who think, learn, believe, respond, and work differently further increasing the cultural gap that must be traversed in order to successfully transfer knowledge. This younger demographic is raised on technology and may not remember a time when there were no computers, video games, mobile devices, and the Internet. Members of this younger generation are "digital natives" who bring different skillsets to the workplace such as stronger visual memory capabilities, greater memory retention and recall, and self-actualization. Non-profit and civil servant employers must learn to take advantage of these unique traits in order to overcome the challenges presented by this demographic shift.
\end{abstract}

Keywords: Baby Boomer generation, demographic shift, employee retention, Gamer generation, knowledge transfer

\section{Introduction}

A significant shift in the demographics of the global workplace is currently in process (Carstens \& Beck, 2005). Employees, largely Baby Boomers (or Boomers), who have worked for the same companies for years are reaching retirement age in droves at a rate of 10,000 per day, every day for the next 20 years (DePass, 2012). These Boomers are often replaced by a member of the Gamer generation, someone born between the years 1979 and 2000 (Carstens \& Beck, 2005). To emphasize the significance of this generational shift, it's not uncommon for the retiree to have amassed more years of work experience than the age of their replacement.

An additional complexity in the current demographic shift is that the wave of Gamer aged employees think, learn, believe, respond, work, and play far differently than the retirees ever did. This younger demographic was raised on technology. In fact, they have never known a time when there wasn't technology; this distinction makes them "digital natives" (Prensky, 2006). Because they were raised immersed in technology, younger employees bring an entirely different skillset to the workplace. In order for organizations to stay competitive, they must quickly learn how to adapt to this new demographic to take advantage of their technical, natural-born talents. This is especially true for companies in the industrial realm as younger people have grown up using a different set of repetitive motions, have stronger visual memory capabilities (Hershatter \& Epstein, 2010), are tactile learning-based (Cairncross \& Buultjens, 2009), and are more experienced at memory retention and recall (Oyen \& Bebko, 1996) because of their familiarity with technology.

As knowledge transfer from Boomers to their much younger replacements (Kapp, 2007) and retention of Gamers (Sujansky, 2009) are two of the biggest obstacles facing organizations today, it becomes critical that government organizations and non-profit companies working in public service create an environment that accommodates their incoming workforce. Accommodation means understanding the differences between Gamers and Boomers and what those differences might mean for the tools provided by the organization for all employees to perform their jobs. Tools can come in many forms, including training, communication, knowledge transfer, and scheduling. 


\section{Demographic Shift in the Workforce}

The government and non-profit workplace is comprised of an ever changing, ever evolving demographic that for the first time in its history has employees from many different generations working side by side and closely with people who are either as young as their children or as old as their parents (Gursoy, Maier, \& Chi, 2007). Multiple generations had worked together in the past, but the dynamic was much different than it is today. Members of different generations were previously separated from each other within the public service sector by job description and organizational hierarchy. For example, middle-aged employees tended to be in middle management and the younger generation employees were elsewhere in the "individual contribute" levels of the organization (Gursoy et al., 2007). Contact with similarly aged employees was mostly at the peer level or only upwards one level via the reporting manager (Kogan, 2001). Generational mixing was minimal and protected by organizational protocol. Older, veteran employees made decisions and these decisions were in turn communicated down to the younger employees (Gursoy et al., 2007). This older generation management style was based on the top-down, bureaucratic approach (Hogan, Curphy, \& Hogan, 1994) which describes how the leaders at the top of the hierarchical paradigm were in direct control of all of the decisions and people in the levels beneath them. This management archetype was derived from the Industrial Age (Gronn, 2002). With this type of leadership and decision making model, organizational success and failure could be explained by the older generation manager's attributes (Gursoy et al., 2007).

What happens to the organizations operating under this Industrial Age decision-making hierarchy when the older employees, the Boomers, retire? DePass (2012) has determined that 10,000 Boomers will reach the age of 65, retiring age, every day for the next 20 years. His research goes on to identify that the United States isn't alone. This is a global epidemic affecting Europe, Japan (Halse \& Mallinson, 2009), China (Kapp, 2007), Australia (Solnet \& Hood, 2008), and South Africa (Wessels \& Steenkamp, 2009). Furthermore, based on the argument presented here, one can presume that Boomers are leaving the workplace en masse and they are taking with them decades of decision making experience that will not easily be replaced by their successors.

One of the biggest, most difficult issues that has been facing non-profit organizations and government agencies employing civil servants since January, 2011 - the date on which the oldest Boomers started turning 65 (Stone, Schwartz, Broderick, \& Deaton, 2010) — and will be through 2030 is the transfer of knowledge from retirees to Gamers (Carstens \& Beck, 2005). This demographic shift is happening quickly and at a time when organizations can ill afford to slow down long enough for these younger employees to catch up. Kapp (2007) states: "Because of this, the organizations that are successful at transferring their business acumen and years of work-specific experience to the incoming Gamer generation will also be successful in their industry and in out-lasting their competition. Those capable of this transfer will experience benefits in productivity, quality, and profitability. Government, public, and non-profit service organizations that are incapable of a successful knowledge transfer will experience dire results."

Another substantial risk with just as important of an impact regarding an organization's stability during this demographic shift is employee retention and avoiding unwanted turnover. Unless organizations are able to retain these new, young professionals, they stand to risk losing billions of dollars on wasted employee training and lost productivity (Sujansky, 2009). Training Gamer employees is critical but retaining them is paramount to the future of organizational survival of this demographic shift (Smith \& Galbraith, 2012).

So what makes knowledge transfer and employee retention so much more difficult during this demographic shift compared to previous shifts in the public servant workforce? The difficulty lies, quite simply, in the extreme differences between the employees leaving the workplace and those taking their place; i.e. Gamers versus Boomers. Gamers entering the workplace, or in the process of establishing themselves in it, have grown up in a vastly different world than the departing Boomers (Kapp, 2007). In fact, research shows that the generation gap is largest and most significant between Gamers and Boomers (Anantatmula \& Shrivastav, 2012). Gamers differ from Boomers in many ways: from their perception regarding the need to always be connected, to reporting hierarchy preferences, to how they prefer to learn, and to the means in which they wish to communicate with peers and authority figures alike. Where Boomers were digital immigrants (Kapp, 2007), Gamers are digital natives (Prensky, 2006). Digital natives can be expected to enter the digital age of the workforce with a significantly different, and more advanced skillset that works well to evolve the organization in which they are employed. Gamers have a different perception of life and work due to ideas that were engrained into them through playing video games, constantly interacting with handheld devices, and not being able to remember a time when they couldn't surf the web to find instant information for "Just-In-Time" learning (Kapp, 2007). This is why training and retaining them is increasingly important to companies who wish to stay relevant in a negative economy. 


\section{Different Generations in the Workplace}

Generations and the members, or cohorts, contained within them are identified as a group of people sharing the same birth years and the same significant life events at the critical stages in their childhood and adolescent development (Kupperschmidt, 2000). Put another way, generations are meaningful psychological variables that capture the culture of its members' upbringing during a specific time period (Twenge \& Campbell, 2008). A generational group includes those who share historical or social life experiences where the effects of said experiences are somewhat stable over the course of their lives (Westerman \& Yamamura, 2007). There are dramatic differences between each generation's value sets; an employee's work values are influenced more by generational experiences than by age and maturation (Smola \& Sutton, 2002).

Regarding generational cohort age, Figure 1 defines the boundaries for all generations still present in the workforce of today. Figure 2 provides an outlook on the actual and projected percentages of members of each generation in the workforce in 10-year intervals (De Meuse \& Mlodzik, 2010). Note that in the figure below, Generation Z (or Gen-Zers) represents the youngest of all cohorts which is following the Gamers and is not expected to enter the workforce for another six to eight years.

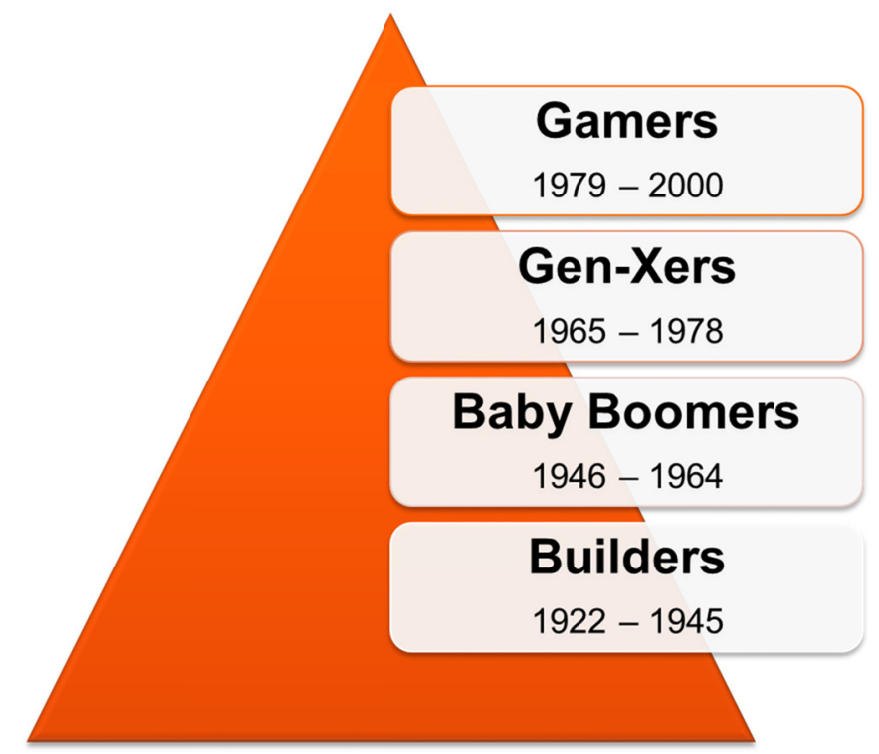

Figure 1. Generational boundaries for the generations currently comprising the workforce 


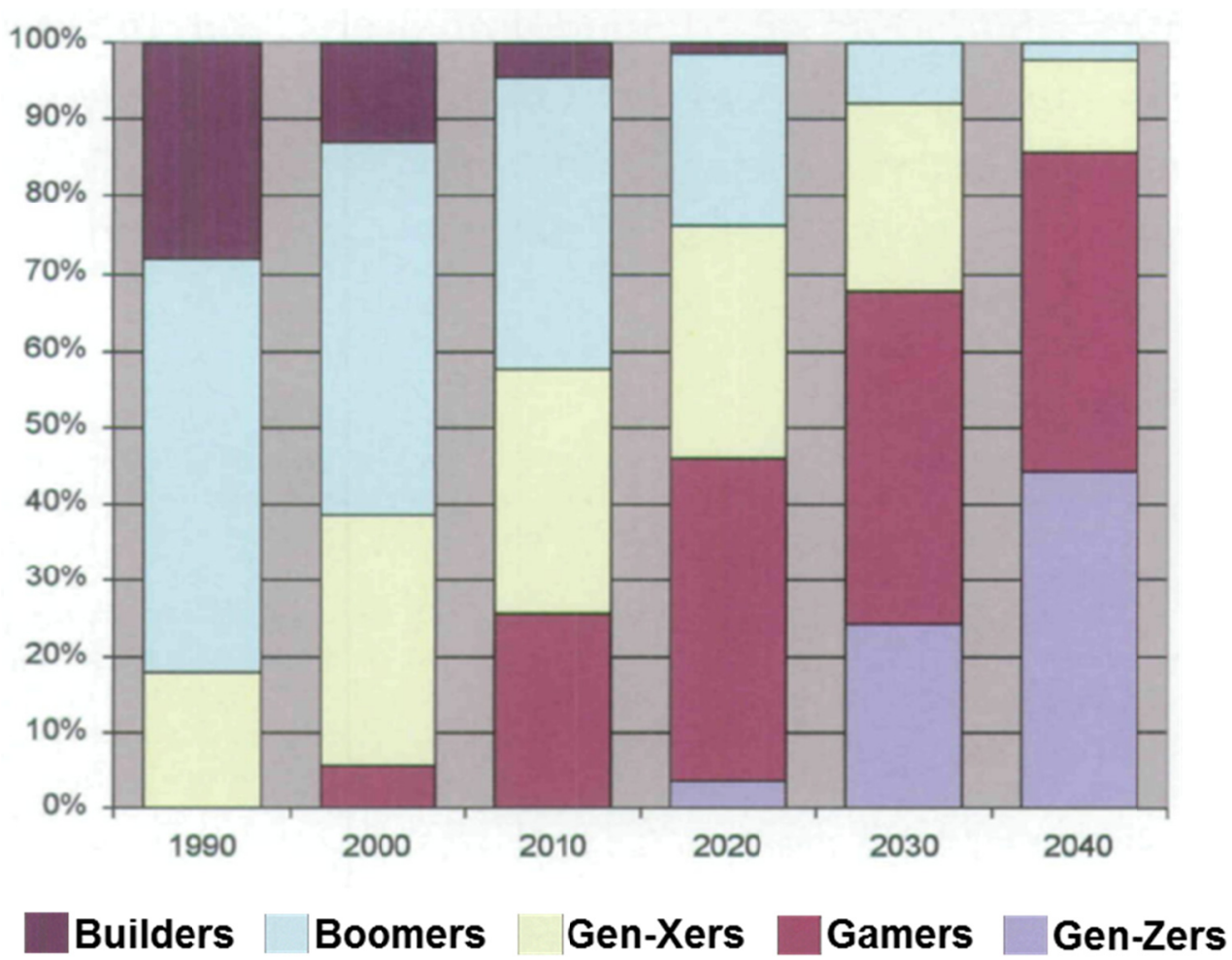

Figure 2. Actual/projected percentages of cohorts in the global workforce (De Meuse \& Mlodzik, 2010)

\section{Key Characteristics of the Gamer Generation}

The current generation entering the workforce and replacing the Baby Boomers is the Gamer Generation. This generation, the Gamers as they will be regarded for the purposes of this study, is more widely known as Generation Y (Cairncross \& Buultjens, 2009) or the Millennials (Berenson, 2005). Based on the definitions of these generational type casts and including the consideration of when the technology that influenced Gamers the most came into existence, the boundary years in which a member of the Gamer Generation was born are between 1979 and 2000.

Gamers have a number of key characteristics but perhaps the most notable is the nomination by Solnet and Hood (2008) that their generation is the first to be considered self-actualized based on the Maslow's Hierarchy of Needs (Figure 3). Maslow (1970) states that higher order needs only come into focus for individuals when lower order needs are satisfied. Unlike previous generations, some researchers believe that Gamers are entering the workforce at self-actualization levels because of their desire to bring creativity to work, to problem solve, and to find meaning in what they do (Espinoza, Ukleja, \& Rusch, 2010). All other esteem, love, safety, and physiological needs have already been met. It should be noted that this self-actualized state by the Gamer generation is specific to their desire upon entrance into the workforce and not necessarily applicable to their overall need when taking all components of their lives into consideration. 


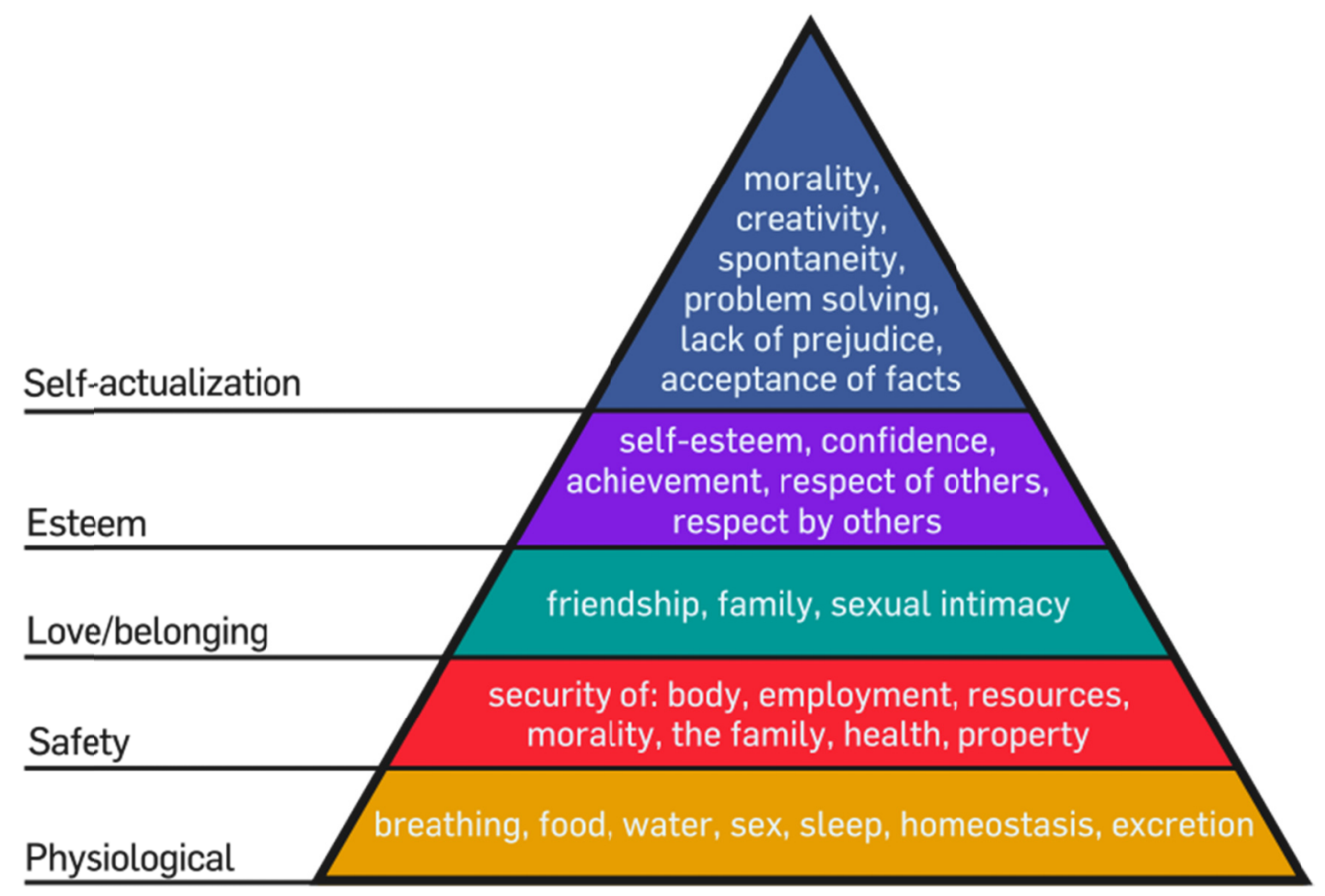

Figure 3. Maslow's Hierarchy of Needs (Simons, Irwin, \& Drinnien, 1987)

Maslow originally developed his hierarchy of needs model to explain individual motivation but Espinoza et al. (2010) found the concept useful in explaining differences about the generations and their "orientations toward the workplace." Their findings go on to explain that, due to societal change, the four generations in the workplace today entered their work lives at different places on Maslow's hierarchy. Espinoza et al. (2010) goes further to detail where each generation was at the start of their careers in terms of need:

- The Builders began their working careers at the safety level due to growing up in less prosperous times where a paycheck was all that was needed to motivate someone (Espinoza et al., 2010).

- The Baby Boomers entered at the love and belonging level because of post-war prosperity where they believed patience and serving their time would lead to prosperity (Espinoza et al., 2010).

- Gen-Xers started at the esteem level due to being born into a time when the economy was even stronger than with the Boomers; meritocracy provided their need for belonging and so they often struggle with esteem and confidence issues (Espinoza et al., 2010).

- Gamers are entering the workplace at self-actualization levels because of their desire to bring creativity to work, to problem solve, and to find meaning in what they do (Espinoza et al., 2010).

If self-actualization needs are driving factors behind what motivates Gamers and fulfills them, it can be inferred that a lack of self-actualization is what may lead young employees to be unfulfilled, causing them to leave their job and look elsewhere. Interviews of members of the Gamer generation by Twenge and Campbell (2008) revealed that Gamers believe they should be both proud of and fulfilled by their jobs. Job positions that prevent Gamers from achieving their self-actualization needs are ones that won't be held by Gamers very long.

The ability to be self-actualized largely starts with the fact that Gamers are "digital natives" (Kapp, 2007) meaning that they have grown up immersed in technology. Gamers, for the most part, have always been able to access information immediately via the Internet and socialize themselves to the world using social media making them an instant gratification generation (Cairncross \& Buultjens, 2009). They are also a generation that is more comfortable in a virtual world (Eisner, 2005) yet are still considered more social—all be it on a more superficial social basis given their invention of and ties to online social media - than previous generations (Hansen, 2008). This comes at a price, however, given that growing up in a virtual world causes them to have a lack of social graces (Anantatmula \& Shrivastav, 2012) and soft skills such as listening, communication, and independent 
thinking (Eisner, 2005). Other challenges that Gamers may face as they traverse into the work space is their lack of respect for authority and overconfidence (Cairncross \& Buultjens, 2009) as well as their strong narcissistic tendencies (Twenge \& Campbell, 2003). Despite these negative character depictions, Gamers are often eager to learn and prefer to be matched with challenging work that pushes them (Eisner, 2005). This same desire to feel challenged is also the same reason Gamers have garnered the "here today, gone tomorrow" reputation (Gursoy et al., 2007) meaning that they are more likely to keep their career options open if their requirements aren't met despite their aspirations to remain at a single organization (Hershatter \& Epstein, 2010).

All of the many dozens of characteristics specific to Gamers aside, the reality is that this youngest generation in the workplace has a new belief system that is unique to them. Out of all of the research performed for this study, the following four beliefs summarize the mentality of the Gamer Generation.

\subsection{Principle 1: The World is an equal yet competitive Place and Needs a Hero}

Children in the Gamer generation grew up with what psychologists call "positive tolerance" (Tulgan, 2009) which means that differences of any kind are acceptable. Uniqueness is the centerpiece of identity as long as it's also understood that regardless of said differences, everyone is made equal and everyone is worth an equal amount. Despite the equality and the expected distribution of "trophies" for minimal effort, Gamers understand that said trophies, or rewards, typically aren't equal in value. Video games have taught them this including that winning (getting there first, achieving the goal, getting the highest score) does certainly matter (Carstens \& Beck, 2005). Carstens and Beck (2005) go on to state that Gamers recognize the need to stand out is important as being the "hero" is crucial to success. So in essence, "everyone is equal, rewards are not; someone is expected to win so it might as well be me."

\subsection{Principle 2: Trial and Error Leads to Victory}

Regardless of validity, one of the biggest lessons that video games and mobile technology instill into younger users is that instead of trying to seek one answer to a problem or conflict, Gamers should try as many "solutions" as possible and see what happens as a result. Based on this theory, there are many potential paths to resolution. Gamers understand that victory is always possible because the software designer wouldn't have made the game or application without a solution. Also, because the cost of failure in a game or with an "app" is of little to no consequence based on the task, all that is required of the user is to merely start over and try again (Carstens \& Beck, 2005). This same perception that failure comes with little to no expense may have originated in a virtual world but is carried over into the real one.

\subsection{Principle 3: Self-directed Learning is Best}

Gamers don't think like previous generations and are largely seen as self-educating due to their introduction to the Internet at a young age and the ability to use search engines to find exactly what they want, when they want it. This creates the "Just-In-Time" method of learning that they expect because it places what they want to know at their fingertips in as little or as much quantities as they specify. Regarding data quantity, Gamers prefer to consume very small bits of information, the bare minimum of material required for them to complete a task just before the skill is needed (Beck \& Wade, 2004).

Learning in small bits seems to build upon Thompson's (2007) neurological studies that indicate Gamers are less able to remember simple information than older generations. While this is certainly a negative trait, it is also shown to come with benefits as identified by Siemens' (2005) Theory of Connectivism which states that Gamers make up for this cognitive flaw by being significantly better at forming connections and evaluating information to create knowledge than any generation before them. Hence, learning via small chunks of information allows them to process how that information might connect to other chunks, thus drawing conclusions that might not have otherwise been identified had learning occurred over a vast amount of information.

Taking all of these learning preferences into account, the way the Gamer generation learns has been called "mediated immersion" and is characterized by this great influence of media usage combined with more collective sharing and learning (Oblinger \& Oblinger, 2005).

\subsection{Principle 4: Learn from Peers; Distrust Authoritative Figures}

Given that over $50 \%$ of the Gamer generation over-values their skillset (Beck \& Wade, 2004) and that they've been advised by their parents to be wary of those in management, there is certainly a lack of a trust component on the part of Gamers for their managers and other authoritative figures. Also, considering that peers, fellow Gamers, were the teachers who taught Gamers to achieve success in the virtual and social media worlds, a cohort was quickly created where, instead of relying on one's parents for advice and guidance, Gamers turned to their friends for help. This engrained the concept that peers are to be trusted and utilized whereas authoritative figures 
don't understand the concepts of the new world enough to be of any benefit (Beck \& Wade, 2004).

\subsection{Unique Skillsets Gamers Bring to the Workforce}

Research suggests that a physiological difference exists between the brains of "digital natives" (Prensky, 2006) and adults from previous generations. Specifically, research identifies that early exposure of infants and young children to various stimuli can affect neurological development along with the evolution of neural networks. Children reared well immersed in media- and technology-rich environments tend to think and learn differently because they are, in fact, physiologically different from those teaching them (Fausto-Sterling, 2000). Additional research affirms these findings believing that the human brain's digital input has "rewired" it, allowing the brain to respond faster, sift out information, and recall less (Woods, 2006).

A study performed in 2003 exposed that Gamers could consume the equivalent of 31 hours of media and data via multiple mediums within a 24 hour period (Weiss, 2003). Gamers possess a natural multitasking technique to ingest nearly $30 \%$ more data and information in the same period of time as their Generation X and Boomer counterparts. But multitasking is a controversial concept given that the human brain performs tasks by a single-threaded means and not in a multi-threaded way that the term multitasking implies. Adler and Benbunan-Fich (2012) explain that multitasking is often used to explain the function that cognitive switching performs (i.e. the resources consumed by the brain when changing from one task to another). In Gamers, the amount of time needed to perform a cognitive switch is less because they have been trained by games and social media to routinize tasks that Boomers or other generations would typically have to think about. Being immersed in data has forced Gamers to learn how to perform rapid task switching (Beck \& Wade, 2004) thus giving the appearance of being more effective at completing multiple tasks at once.

Findings also state that Gamers are more effective in some areas like responding to visual stimulation, multitasking, and filtering information. Gamers are less adept, however, in face-to-face interaction and deciphering non-verbal cues. Small states that these advantages and disadvantages are derived from actual changes in the neural circuitry that developed through the acquisition and repetition of technology-based skills. (Hershatter \& Epstein, 2010).

While it has been discussed that Gamers are visual learners, research has shown them to be kinesthetic learners as well (Manuel, 2002). Kinesthetic learning, also known as tactile learning, is a learning style identified by Leite, Shi, and Svinicki (2009) in that "learning takes place by the student (or employee in this case) carrying out a physical activity rather than listening to a lecture or watching a demonstration."

\subsection{Key Technologies that Aided in the Development of Gamer Characteristics}

Computer applications, most specifically games, "apps", and the Internet are designed such that the balance of required information-processing is shifted from verbal to visual. This new skillset specifically enhances the cognitive abilities dealing with visual intelligence such as spatial representation, iconic recognition, and visual attention. These are the same skills required to successfully navigate video games and many other computer applications (Subrahmanyam, Greenfield, Kraut, \& Gross, 2001). Johnson (2005) notes that these skills, learned in a virtual world, do in fact directly translate into the real world.

Video games are the key technology that helped develop the Gamers into the self-actualized generational cohort that they are today but all interactive technology is relevant in this discussion. The personal computer started the phenomenon as it introduced a faster computing capability, became one of the first gaming platforms, and brought the Internet into homes. The Internet, while not necessarily equal in influence to that of the video game, is a very important factor. "Just-in-Time" learning wouldn't be possible without it; neither would the ease of global communication. The combination of all technologies into single platforms that can be hosted via family-centric media consoles or individual smart devices has furthered, and even quickened the development of these generational characteristics. It will be even more interesting to see how Generation Z, the successors of the Gamers, develops based on these technological advances.

\section{Gamers versus Boomers}

The present shift in workforce demographics is seeing Baby Boomer-aged retirees being replaced by employees aged 35 years and younger who think, learn, believe, respond, and work far differently than the retirees ever did. The differences between generations are notable throughout their entire life cycle but the differences are really visible at the age when they graduated (from college in this case) and entered the workforce as shown in Table 1. The most notable shift is the change from Boomers being middle-class Caucasian males to Gamers being mostly diverse women of all races, ages, and financial status. 
Table 1. Demographic comparison of boomers and gamers in college and entering the workforce (Black, 2010)

\begin{tabular}{ll}
\hline \multicolumn{1}{c}{ Baby Boomers } & \multicolumn{1}{c}{ Gamers } \\
\hline Caucasian & All races and ethnicities \\
Majority were men & Majority are women \\
Full-time college enrollment & Growing part-time college enrollment \\
Aged 18-22 & Ages 18 and older \\
Graduated in four years & Graduated in six years or more \\
Abled & Abled and disabled \\
Presumed heterosexual & All sexual orientations \\
Native-born to Unites States & Increasing number of immigrants \\
Middle-class & Increasingly diverse culture, economic, and geographic backgrounds \\
\hline
\end{tabular}

Another point of reference in characteristics of the then Boomers and now Gamers is when they made their transition from college to the working world and the positives and negatives each introduced into the workplace. One of the bigger characteristic distinctions to note is how each generation viewed itself contrasted with the amount of skill each brought to the workplace (as shown in Table 2). For example, Boomers were unsure of themselves and their abilities, however, they were more prepared for the work environment that they entered. Gamers on the other hand are assertive and confident yet lack the basic skills needed to immediately be successful in their work environment. This has less to do with academic skills and more to do with the soft skills that are lost on Gamers due to their reliance on technology to communicate.

Table 2. Characteristics of boomers and gamers as they left college and entered the workplace (Black, 2010)

\begin{tabular}{ll}
\hline \multicolumn{1}{c}{ Baby Boomers } & \multicolumn{1}{c}{ Gamers } \\
\hline Politically more liberal & Politically more conservative or independent \\
General learning orientation & Vocational / career orientation \\
Family / self-financed & Government / family / self-financed \\
Academically prepared & Lacking basic skills \\
Competitive & Collaborative \\
Worked and studied alone & Group work, team work \\
Lack of experience with diversity & Acceptance of diversity, more tolerant \\
Unsure of self & Assertive and confident \\
Low debt after college & High debt and defaults on loans after college \\
Friendships bound by proximity & Friendships not bound by geographical limits \\
Idealist, any problem can be solved & Cynical, aware of global warning and other world issues but still \\
& hopeful \\
Rejection of organized religion & Growing importance of spirituality and religion \\
Took responsibility for self & Growth of helicopter parents who hover and assume responsibility \\
& for college-age children \\
Acceptance of institutional structure & More demanding consumers with customer expectations of \\
& immediate service \\
Feared that their leaders would be & Fear that their friends will be assassinated* \\
assassinated* & \\
A privilege to attend college & An expectation to attend college; entitlement \\
Family stability & Family instability \\
Physically fit & Growing problem of obesity \\
Rejection of values of parents and society & Sharing values of parents and society \\
Mentally healthy & Less mentally healthy \\
Dependent upon note-taking & Dependent on technology \\
\hline
\end{tabular}

Note: *From Espinoza et at., 2010 
Some of the key differences in the belief principles found in Boomers and Gamers in the workplace include a perceived set of boundaries required by the Boomers while the Gamers tend to operate without clearly defined boundaries as is highlighted in how they spend, train, communicate, and lead. Table 3 identifies the most significant difference between Boomers and Gamers is how they learn. The reliance on auditory learning for Boomers is replaced by visual and tactile learning for Gamers.

Table 3. Differences in belief principles between boomers and gamers currently in the workforce (Cairncross \& Buultjens, 2009)

\begin{tabular}{|c|c|c|}
\hline Principles & Baby Boomers & Gamers \\
\hline Values & Some absolutes, variety, freedom & Few absolutes, lifestyle, fun \\
\hline Motivations & Individuality, achievement, relatable & Own-community, self-discovery, relational \\
\hline Decision Making & Experts, information, brand-switchers & Friends, anecdotes, little brand loyalty \\
\hline Earning \& Spending & $\begin{array}{l}\text { Confident investors, medium-term } \\
\text { goals, credit-savvy }\end{array}$ & $\begin{array}{l}\text { Uncertain-spenders, short-term wants, } \\
\text { credit-dependent }\end{array}$ \\
\hline Learning Styles & $\begin{array}{l}\text { Auditory / visual, analysis-focused, } \\
\text { dialogue }\end{array}$ & $\begin{array}{l}\text { Visual / kinesthetic, narrative / metaphors, } \\
\text { multi-sensory }\end{array}$ \\
\hline $\begin{array}{l}\text { Marketing \& } \\
\text { Communication }\end{array}$ & Descriptive, direct, below the line & Participative, viral, through their friends \\
\hline $\begin{array}{l}\text { Training } \\
\text { Environment }\end{array}$ & $\begin{array}{l}\text { Round-table style, planned, relaxed } \\
\text { ambience }\end{array}$ & Unstructured, spontaneous, interactive \\
\hline $\begin{array}{l}\text { Management \& } \\
\text { Leadership }\end{array}$ & Cooperation, competency, doers & Consensus, creativity, feelers \\
\hline
\end{tabular}

Boomers and Gamers have differing perceptions pertaining to different aspects of an organization and, most specifically, the technology component and how it relates to the workplace. The dependency on technology by Gamers at the workplace is an obvious difference that will make training them difficult especially for a generation like the Baby Boomers who perceive technology as more of a "nice to have" as opposed to a "way of life". Table 4 is the most crucial comparison of Gamers and Boomers as it identifies the differences in how the two cohorts approach training, work tasks, and work tools. The distinction between Gamers as digital natives and Boomers as digital immigrants due to their concern for technology (Gursoy et al., 2007) has been previously discussed yet it is the most important distinction. Gamers' reliance on search engines putting needed information within quick grasp has made the structured learning approach of concentration-heavy reading undesirable. Informal communication is needed in order to continue a Gamer's desire to multitask. Face-to-face conversation reduces the number of functions that can be performed at once. Gamers are even particular about their data given their preference to process information on their own terms; their terms often being as much information in a single view as possible which is generally overwhelming for the older generations. Any tasks that take more time are viewed as impedance to a Gamer's instinctive desire to rise to the top as quickly as possible (Kapp, 2007).

Table 4. Differing technology-based perceptions of boomers and gamers (Kapp, 2007)

\begin{tabular}{|c|c|c|}
\hline Perceptions & Baby Boomers & Gamers \\
\hline Knowledge & $\begin{array}{l}\text { Structured (books, memos, standard } \\
\text { operating procedures) }\end{array}$ & $\begin{array}{l}\text { Unstructured (instant messaging, } \\
\text { blog, e-mail) }\end{array}$ \\
\hline Organizational Structure & Hierarchical team-based structure & Level playing field, equality \\
\hline Communication Channels & Formal (face-to-face, telephone calls) & $\begin{array}{l}\text { Informal (instant messaging, e-mail, } \\
\text { text messages) }\end{array}$ \\
\hline Software Applications & Interface and information are separate & Information is the interface \\
\hline Career Advancement & Patient ascent & Impatient rapid ascent \\
\hline Learning Environment & Classroom & E-learning \\
\hline Gadgets & Fun to have, unnecessary & Essential \\
\hline Video Games & Distraction, entertainment, waste of time & Way of life \\
\hline Information Processing & Linear & Multitasking (perceived) \\
\hline Technology Comfort Level & Digital immigrant & Digital native \\
\hline
\end{tabular}




\section{Impact of Gamers on the Design of Work Tasks and Devices}

Just as Boomers had misconceptions regarding members of the Generation X cohort, Gamers will have to overcome a similar set of misconceptions from older peers and authoritative figures in the workplace. Also, in order for an organization to truly understand and take advantage of what makes the Gamer generation unique, they must first identify their perceptions of Gamers and determine if so called prevalent traits associated with this youngest cohort in the workplace are misconceptions or realities.

\subsection{Perception 1: Lazy Group of Slackers}

Technology is often attributed to the perceived laziness of the Gamer generation due to the ability to discovery and utilize shortcuts in order to achieve tasks (Hansen, 2008). With the answers always seemingly at their fingertips, older generations believe that Gamers are only as useful as the knowledge that they can find within the first few minutes of looking and that they struggle when real work must be done to accomplish a task. Based on research performed by the Kenexa Research Institute, the reality isn't quite as black and white. Upon analysis of the different generations, they found that the attitudes of Gamers towards work are very similar to those of the preceding Boomers and Gen-Xers. In fact, because Gamers are the generation largely born to the Boomers, a generation known for its emphasis on hard work, Kenexa's research shows that Gamers are highly likely to turn out better than their predecessors when they are the same age (Kingsun, 2011). Beck and Wade (2004) performed an extensive survey of this youngest cohort and their findings, that Gamers prefer their pay and bonuses to be based on actual performance rather than a set salary, indicate quite the opposite of a lazy, slacker mentality. Based on these survey results, Gamers appear to understand their personal success depends on adding value to the enterprise, something that cannot be achieved while exhibiting lazy characteristics (Beck \& Wade, 2004).

\subsection{Perception 2: Lacking in Concentration}

Similar to Perception 1, this observation is often attributed to the over indulgence of too much technology which has not only allowed the Gamer generation to perceivably multitask but has in fact encouraged it (Hansen, 2008). For older generations in the workforce, doing two or more tasks at once can be viewed as disrespectful. This implies that the person performing the tasks isn't that serious about any of them (Beck \& Wade, 2004). Regardless, a new worldwide technology environment has been created where new devices allow the integration, and saturation to some extent, of multiple tasks through usage of these tools. There are clear increases in the number of multitasked task combinations from the older generations to the Gamers. Carrier, Cheever, Rosen, Benitez, and Chang (2009) found that significant increase of multitasking from one generation to the next (i.e. from Boomer to Gen-Xer to Gamer) there by validating what many organizations already suspect: the youngest generation in the workplace does in fact multitask more than any other generation. Their research goes on to conclude that, regardless of generation, the patterns of choices of which tasks to combine for multitasking are extremely similar; meaning that both Boomers and Gamers would chose the same tasks to perform simultaneously. Their research identified that Gamers find it easier than previous generations to multitask and that the task combinations are less likely to be difficult (Carrier, Cheever, Rosen, Benitez, \& Chang, 2009). Based on this information, it could be concluded that, not only are Gamers performing multiple tasks more often, they are better at it.

\subsection{Perception 3: Poor Communication Skills}

Hansen (2008) believes that Gamers are some of the more social of any generation before them but as Eisner (2005) points out, they can lack the soft skills required of them in a work environment. Just as with this current work demographic dynamic, "communication modalities" have posed problems between generations in the past. Boomers value face-to-face communication and have no resolve for leaving their desk, walking over to a colleague located in another office location to ask questions. Gamers, on the other hand, favor instant messaging, text messaging, and emails. Many are most comfortable with digital messages and prefer the ease provided with this form of communication as opposed to having a face-to-face conversation or picking up the telephone (Glass, 2007). Glass (2007) explains that the Gamers' comfort with digital communications can lead to workplace conflicts when management feels that the sharing of bad news warrants more than an email. Problems can also arise when younger workers aren't developing more personal relationships with colleagues, managers, direct reports, and clients all because they have little interest in conversing with them face-to-face (Glass, 2007). The difference from this generation and those that preceded it is that interaction is through a digital medium teaching Gamers to be more comfortable when communicating with someone else through a device of some kind (be it a game console, a computer, or a mobile handheld device). The key for organizations is to realize and accept that the youngest cohort in the workplace communicates very well; they just do it differently through new techniques (Hansen, 2008). This high level of social-ability doesn't excuse Gamers from their lack of soft skills, however, 
and so organizations must utilize new communication techniques to train younger employees on the importance of the more personable expectations.

\subsection{Perception 4: Weaker Work Ethic}

Boomers and Gen-Xers often believe that Gamers do not work as hard or long as they do because they aren't "punching the clock" and working a standardized 8:00 AM to 5:00 PM work day (Glass, 2007). The majority of this perception is derived from the shifting workplace dynamic that is taking place due to advancements in communication technology and the speed in which data transfer can occur. This shifting dynamic includes the popularity of organizations to allow remote locations, telecommuting, and having virtual offices (Glass, 2007). The reality is that the Gamer generation is the most educated workforce and because of their high education level, Gamers desire work that has meaning. Because they are seeking a greater fulfillment, they are only willing to work hard at jobs that provide them that sense of importance (Hansen, 2008). Also, the stereotype of Gamers possessing a weaker work ethic is not supported by the data (as measured by numbers of hours worked and work patterns) (Deal, Altman, \& Rogelberg, 2010). The Families and Work Institute (2005) found that workers overall, meaning all generations in the workforce today, are working longer hours than in the past. There are no differences between the hours worked by Gamers and Gen-Xers at the same age. They also found that as of 2002, Gen-Xers were working more hours than were Boomers at the same age in 1977 (Families and Work Institute, 2005). Based on this logic, if Gamers and Gen-Xers are working the same number of hours and Gen-Xers are working more hours than Boomers did, then one could conclude that Gamers are in fact working longer hours than Boomers and, overall, do not have a weaker work ethic.

\subsection{Additional Workplace Task and Tools Implications}

Referring back to the need to conduct self-directed learning, Gamers are not focused on books and reading (Kapp, 2007). In the interviews of Gamers performed by Beck and Wade (2004), they found that while some participates would be willing to read small manuals, any form of written instruction perceived to be long and tedious would be ignored. In its place, Gamers would resort to Internet searches in order to find the information. Further still, many Gamers said that they would resort to another principle, trial and error, before taking the time to read a lengthy instruction set (Beck \& Wade, 2004). Supporting this information is a study that found because of the availability of visual media, Gamers text literacy may be less well developed than previous cohorts (Milliron, 2008). In her study, Milliron (2008) goes on to say that college graduates from the Gamer generation will lack the functional skills historically associated with a bachelor's degree. Since most Gamers do not have "active reading habits," even when reading does occur, the quality of the reading is generally less focused. Reading and focus are vital aspects of learning and highly correlated with professional success (Milliron, 2008). Furthermore, Gamers are known to be more comfortable in "image-rich" environments than those comprised of text. They may often refuse to read large amounts of text and prefer to do things in order to learn, as opposed to only just thinking, listening, and talking about things (Wessels \& Steenkamp, 2009).

\section{Leveraging Gamers' Characteristics Into Tool Design}

Managers who aren't members of the Gamer cohort yet work in non-profit or government organizations experiencing this demographic shift may not be overly pleased with the information presented in this study about their future workforce. However, excited or otherwise, managers that are capable of capitalizing on Gamer differences and incorporating their younger employees more quickly into their civil servant workforce may add much needed relevance in a struggling economy.

\subsection{Recommendation 1: Access to Technology}

Due to their desire to be creative, solve problems, and their pursuit of factual data, Gamers are more likely to be aware of the need for constant skill development and updating their technology toolkit (Westerman \& Yamamura, 2007). Halse and Mallison (2009) validate this point when they identify that Gamer's thinking is shaped and defined through learning in the form of new technologies. In this case, their technology toolkit equates to modern technology allowing Gamers to show their creativity and productivity aiding them in solving problems quickly. Studies performed on the Gamer generation have stressed the importance of placing quick access to data and gadgets into the workplace as Gamers are attracted to modern technology (Cairncross \& Buultjens, 2009). Cairncross and Buultjens (2009) go on to say that the innovative companies that implement modern technology into their organization benefit from lower turnover and higher morale from their youngest cohort employees.

Kapp (2007) stresses the importance on organizations finding methods for faster deployment of instruction stating that these tools, the ones needed to bridge the gap between archaic learning methods and how Gamers learn best, already exist today via the modern technology used in employees' lives outside of work. Blackburn 
(2011) backs this research explaining that Gamers are bringing technology from their personal lives and using it as solutions to their needs in the workplace. Gamers not only want to learn using their consumer-based technology solutions, but, in fact, they must. Some consider that Gamers are often incapable of traditional learning (Kapp, 2007). Their minds and learning habits have been altered too greatly by technology to adhere to old standards and expectations placed on them by perceivably antiquated corporate architecture.

The message here is one that exemplifies the purpose of this research: that Gamers grew up differently, they think differently, and that modern consumer technology works toward and takes advantage of their skillset, be it communication, learning, or problem solving. With the groundwork already completed by the consumer industry, the government, public, and non-profit service space would be well served to model said groundwork as their technological approach to innovation in training or knowledge transfer. Rogers (2003) defines an innovation as “... an idea, practice, or object that is perceived as new by an individual or other unit of adoption." This innovation will likely be new to the organization but it doesn't have to be new to the Gamers who will be using it. In fact, the Gamers will likely know how to use this technical innovation before the organization ever thinks to incorporate it into their toolset. In this sense, the tool itself has created the need (Blackburn, 2011) as opposed to the other way around where needs first beget the tools. Rogers (2003) goes on to define technology as “... a design for instrumental action that reduces the uncertainty in the cause-effect relationships involved in achieving a desired outcome. A technology innovation usually has at least some degree of benefit for its potential adopters." In instances of adoption, Gamers typically take the role as change agents for the organization (Blackburn, 2011).

\subsection{Recommendation 2: Task and Learning Structure}

In order to train and retain Gamers, the work-related material and information must come quickly in small bits as the users demand it while they perform hands on trial and error (Kapp, 2007). These training characteristics may sound awfully similar to what is experienced by a person playing a video game or using a smartphone, but it's also the new real world in business and government. A change has occurred in the dynamic of learning as it compares to a person's age. Learning used to be something that people did less and less as they got older. Now, due to necessity, learning must be continual and ongoing and is embedded into how Gamers want to work (Halse \& Mallinson, 2009).

Regarding innovation, including new technology in the workplace to facilitate learning and knowledge transfer (Wessels \& Steenkamp, 2009), and retaining Gamers themselves, there are a number of ways for organizations to take advantage of the skillsets presented by the youngest cohort. One such method is the two-way mentorship. The two-way mentorship is a means to aid in overcoming the knowledge gap between the Gamers and Boomers, to facilitate the inevitable transfer of knowledge, and to avoid employee retention woes that result from poor information hand-off structures. Bringing new technology to the workplace will distress Boomers but it will provide the mechanism Gamers need to effectively learn (Beck \& Wade, 2004). As Gamers learn organization-specific information that they need to perform their job function and adequately replace the retirees, they should be paired with a Boomer to help them learn whatever technical innovation of which the Gamer is already well experienced. At the same time, the Boomer should impart work experience via informal training including the soft skills that Gamers are often missing (Eisner, 2005). Gamers aren't likely to need the traditional social skills when interfacing within their own cohort but these skills are still appreciated by older generations (Beck \& Wade, 2004).

Regarding structure, Gamers need to feel creative but not at the expense of high-level direction and defined tasks. For a cohort that has expended hundreds of thousands of hours spending their free time adhering to the carefully defined guidelines introduced by games and technology in general, structure is expected especially with tasks that have end goals and team social dynamics. Work projects are good examples that contain equal parts goals and social components. Gamers value performance and so they will bond with their teammates over project successes no matter how insignificant the win (Beck \& Wade, 2004). The desire brought about in the neurotransmitter dopamine by games to search, discover, and reward (Johnson, 2005) is just as prevalent in the working world via projects and corporate goals as it is in the virtual world where many of the Gamers were raised.

Lastly, another significant change in learning outlined by Halse and Mallison (2009) explains that informal learning has become more prevalent and important. The majority of learning is no longer formal but occurs through trial-and-error completion of tasks, personal networks, and via communities of practice which also speaks to the importance of two-way mentorships (Halse \& Mallinson, 2009). The idea isn't to turn the workplace into a video game. However, through incorporating some of the same guidelines and technologies found in the personal lives of the Gamers, the same levels of problem solving and creativity will be instilled into 
the organizational environment allowing for a more productive level of knowledge transfer and a greater opportunity for employee retention.

\section{Conclusion}

A significant shift in the demographics of the global workplace is currently in process (Carstens \& Beck, 2005). Entering the non-profit and civil servant workforce is a new generation of workers born between the years 1979 and 2000 that think, learn, believe, respond, work, and play far differently than the retirees ever did. This younger demographic has never known a time when there wasn't technology; this distinction makes them "digital natives" (Prensky, 2006). In order for government, public, and non-profit service organizations to stay competitive, they must quickly learn how to adapt to this new demographic including how to take advantage of their technical, natural-born talents. This is especially true for companies in the non-profit and civil servant space as younger people have grown up using a different set of repetitive motions, have stronger visual memory capabilities (Hershatter \& Epstein, 2010), are tactile learning-based (Cairncross \& Buultjens, 2009), and are more experienced at memory retention and recall (Oyen \& Bebko, 1996) because of their familiarity with technology. Accommodating these new skillsets means understanding the differences between younger and older employees and what those differences might mean for the tools provided by organizations for all employees to perform their jobs. Tools can come in many forms: training, communication, knowledge transfer, scheduling, etc. and all will need to experience radical changes in order to remain relevant in the working world of today.

\section{References}

Adler, R. F., \& Benbunan-Fich, R. (2012). Juggling on a High Wire: Multitasking Effects on Performance. International Journal of Human-Computer Studies, 70(2), 156-168. http://dx.doi.org/10.1016/j.ijhcs.2011.10.003

Anantatmula, V. S., \& Shrivastav, B. (2012). Evolution of Project Teams for Generation Y Workforce. International Journal of Managing Projects in Business, 5(1), 9-26. http://dx.doi.org/10.1108/17538371211192874

Beck, J. C., \& Wade, M. (2004). Got Game: How the Gamer Generation is Reshaping Business Forever. Boston, MA: Harvard Business School Press Books.

Berenson, A. B. (2005). Presedential Address: From Generation to Generation. American Journal of Obstetrics and Gynecology, 192(6), 1783-1787. http://dx.doi.org/10.1016/j.ajog.2004.12.064

Black, A. (2010, Winter). Gen Y: Who They Are and How They Learn. Educational Horizons, 88(2), 92-101.

Blackburn, H. (2011). Millennials and the Adoption of New Technologies in Libraries Through the Diffusion of Innovations Process. Library Hi Tech, 29(4), 663-677. http://dx.doi.org/10.1108/07378831111189769

Cairncross, G., \& Buultjens, J. (2009). Generation Y and Work in the Tourism and Hospitality Industry: Problem? What Problem? Tourism and Generation Y, 143-154. http://dx.doi.org/10.1079/9781845936013.0143

Carrier, L. M., Cheever, N. A., Rosen, L. D., Benitez, S., \& Chang, J. (2009). Multitasking Across Generations: Multitasking Choices and Difficulty Ratings in Three Generations of Americans. Computers in Human Behavior, 25(2), 483-489. http://dx.doi.org/10.1016/j.chb.2008.10.012

Carstens, A., \& Beck, J. (2005, May/June). Get Ready for the Gamer Generation. TechTrends: Linking Research \& Practice to Improve Learning, 49(3), 22-25. http://dx.doi.org/10.1007/BF02763643

De Meuse, K. P., \& Mlodzik, K. J. (2010, April). A Second Look at Generational Differences in the Workforce: Implications for HR and Talent Management. People \& Strategy, 33(2), 50-58.

Deal, J. J., Altman, D. G., \& Rogelberg, S. G. (2010, June). Millennials at Work: What We Know and What We Need to Do (If Anything). Journal of Business and Psychology, 25(2), 191-199. http://dx.doi.org/10.1007/s10869-010-9177-2

DePass, D. (2012, April 10). Retiring Boomers Complicate Skills Gap. Star Tribune. Minneapolis, MN.

Eisner, S. P. (2005, Fall). Managing Generation Y. SAM Advanced Management Journal, 70(4), 4-15.

Espinoza, C., Ukleja, M., \& Rusch, C. (2010). Managing the Millennials: Discover the Core Competencies for Managing Today's Workforce. Hoboken, NJ: John Wiley \& Sons.

Families and Work Institute. (2005). Generation and Gender in the Workplace. Retrieved July 22, 2012, from Families and Work: http://familiesandwork.org/site/research/reports/genandgender.pdf

Fausto-Sterling, A. (2000, Summer). On Teaching Through the Millennium. Signs: Journal of Women in Culture 
\& Society, 25(4), 1253-1256. http://dx.doi.org/10.1086/495556

Glass, A. (2007). Understanding Generational Differences for Competitive Success. Industrial \& Commercial Training, 39(2), 98-103. http://dx.doi.org/10.1108/00197850710732424

Gronn, P. (2002). Distributed Leadership as a Unit Analysis. The Leadership Quarterly, 13, 423-451. http://dx.doi.org/10.1016/S1048-9843(02)00120-0

Gursoy, D., Maier, T. A., \& Chi, C. G. (2007). Generational Differences: An Examination of Work Values and Generational Gaps in the Hospitality Workforce. International Journal of Hospitality, 27(3), 448-458. http://dx.doi.org/10.1016/j.ijhm.2007.11.002

Halse, M. L., \& Mallinson, B. J. (2009). Investigating Popular Internet Applications as Supporting e-Learning Technologies for Teaching and Learning with Generation Y. International Journal of Education \& Development Using Information \& Communication Technology, 5(5), 58-71.

Hansen, R. S. (2008, April 21). Perception vs. Reality: 10 Truths About the Generation Y. Retrieved July 21, 2012, from Quintessential Careers QuintZine: http://www.quintcareers.com/Gen-Y_workforce.html

Hershatter, A., \& Epstein, M. (2010, June). Millennials and the World of Work: An Organization and Management Perspective. Journal of Business Psychology, 25(2), 211-223. http://dx.doi.org/10.1007/s10869-010-9160-y

Hogan, R., Curphy, G. J., \& Hogan, J. (1994). What We Know About Leadership - Effectiveness and Personality. American Psychologist, 49(6), 493-504. http://dx.doi.org/10.1037/0003-066X.49.6.493

Johnson, S. (2005, July). Your Brain on Video Games. Discover, 26(7), 38-43.

Kapp, K. M. (2007). Gadgets, Games, and Gizmos for Learning: Tools and Techniques for Transferring Know-How from Boomers to Gamers. San Francisco, CA: Pfeiffer.

Kingsun, R. (2011, August 5). Generation 'Not so Bad'. Townsville Bulletin, 20.

Kogan, M. (2001, September 1). Bridging the Gap. Retrieved June 25, 2012, from Government Executive: http://www.govexec.com/magazine/magazine-human-resources-management/2001/09/bridging-the-gap/975 2/

Kupperschmidt, B. R. (2000, September). Multigenerational Employees: Strategies for Effective Management. The Health Care Manager, 19(1), 65-76. http://dx.doi.org/10.1097/00126450-200019010-00011

Leite, W. L., Shi, Y., \& Svinicki, M. (2009, April). Attempted Validation of the Scores of the VARK: Learning Styles Inventory with Multitrait-multimethod Confirmatory Factor Analysis Models. Educational and Psychological Measurement, 70(2), 323-339. http://dx.doi.org/10.1177/0013164409344507

Manuel, K. (2002). Teaching Information Literacy to Generation Y. Journal of Library Administration, 36(1/2), 195-218. http://dx.doi.org/10.1300/J111v36n01_12

Maslow, A. H. (1970). Motivation and Personality (2nd ed.). New York, NY: Harper \& Row.

Milliron, V. (2008, August). Exploring Millennial Student Values and Sociatel Trends. Issues in Accounting Education, 23(3), 405-419. http://dx.doi.org/10.2308/iace.2008.23.3.405

Oblinger, D. G., \& Oblinger, J. L. (2005, May). Educating the Net Generation. EduExec, 24(5), 7.

Oyen, A.-S., \& Bebko, J. M. (1996). The Effects of Computer Games and Lesson Contexts on Children's Mnemonic Strategies. Journal of Experimental Child Psychology, 62(2), 173-189. http://dx.doi.org/10.1006/jecp.1996.0027

Prensky, M. (2006, January). Listen to the Natives. Educational Leadership, 63(4), 8-13.

Rogers, E. M. (2003). Diffusion of Innovations. New York, NY: Free Press.

Siemens, G. (2005, April 5). Connectivism: A Learning Theory for the Digital Age. International Journal of Instructional Technology and Distance Learning. Retrieved July 28, 2012, from http://www.elearnspace.org/Articles/connectivism.htm

Simons, J. A., Irwin, D. B., \& Drinnien, B. A. (1987). Psychology - The Search for Understanding. New York: West Publishing Company.

Smith, S. B., \& Galbraith, Q. (2012, May). Motivating Millennials: Improving Practices in Recruiting, Retaining, and Motivating Younger Library Staff. The Journal of Academic Librarianship, 38(3), 135-144. http://dx.doi.org/10.1016/j.acalib.2012.02.008 
Smola, K. W., \& Sutton, C. D. (2002, June). Generational Differences: Revisiting Generational Work Values for the New Millennium. Journal of Organizational Behavior, 23(4), 363-382. http://dx.doi.org/10.1002/job.147

Solnet, D., \& Hood, A. (2008, December). Generation Y as Hospitality Employees: Framing a Research Agenda. Journal of Hospitality \& Tourism Management, 15(4), 59-68. http://dx.doi.org/10.1375/jhtm.15.59

Stone, A. A., Schwartz, J. E., Broderick, J. E., \& Deaton, A. (2010, June). A Snapshot of the Age Distribution of Psychological Well-being in the United States. Proceedings of the National Academy of Sciences of the United States of America, 107(22). http://dx.doi.org/10.1073/pnas.1003744107

Subrahmanyam, K., Greenfield, P., Kraut, R., \& Gross, E. (2001). The Impact of Computer Use on Children's and Adolescents' Development. Journal of Applied Development Psychology, 22(1), 7-30. http://dx.doi.org/10.1016/S0193-3973(00)00063-0

Sujansky, J. G. (2009). Keeping the Millennials: Why Companies are Losing Billions in Turnover to this Generation - and What to Do About It. Hoboken, NJ: John Wiley \& Sons Inc.

Thompson, C. (2007, September 25). Your Outboard Brain Knows It All. Retrieved July 28, 2012, from Wired: http://www.wired.com/techbiz/people/magazine/15-10/st_thompson

Tulgan, B. (2009). Not Everyone Gets a Trophy: How to Manage Generation Y. San Francisco, CA: Jossey-Bass.

Twenge, J. M., \& Campbell, S. M. (2008, Februrary). Generational Differences in Psychological Traits and Their Impact on the Workplace. Journal of Managerial Psychology, 23(8), 862-877. http://dx.doi.org/10.1108/02683940810904367

Twenge, J. M., \& Campbell, W. K. (2003, February). "Isn't It Fun to Get the Respect That We're Going to Deserve?" Narcissism, Social Rejection, and Aggression. Personality and Social Psychology Bulletin, 29(2), 261-272. http://dx.doi.org/10.1177/0146167202239051

Weiss, M. J. (2003). To Be About to Be. American Demographics, 25(7), 28-36.

Wessels, P. L., \& Steenkamp, L. P. (2009). Generation Y Students: Appropriate Learning Styles and Techning Approaches in the Economic and Management Sciences Facility. South African Journal of Higher Education, 23(5), 1039-1058. http://dx.doi.org/10.4314/sajhe.v23i5.48815

Westerman, J. W., \& Yamamura, J. H. (2007, September). Generational Preferences for Work Environment Fit: Effects on Employee Outcomes. The Career Development International, 12(2), 150-161. http://dx.doi.org/10.1108/13620430710733631

Woods, R. (2006, July 9). The Next Step in Brain Evolution; Report. The Sunday Times, 6.

\section{Copyrights}

Copyright for this article is retained by the author(s), with first publication rights granted to the journal.

This is an open-access article distributed under the terms and conditions of the Creative Commons Attribution license (http://creativecommons.org/licenses/by/3.0/). 